\title{
REPRODUCTIVE BIOLOGY OF FEATHER BACK, CHITAL (Notopterus chitala, Ham.) CULTURED IN A POND OF BANGLADESH
}

\author{
A.H.M. Kohinoor*, D.A. J ahan, M.M. Khan, M.S. Islam and M.G. Hussain \\ Received 19 December 2011, Revised 21 March 2012, Accepted 15 June 2012, Published online 30 June 2012
}

\begin{abstract}
Studies on Gonadosomatic index (GSI), ova diameter and histology of the gonad were performed to understand reproductive biology of Feather back, Chital (Notopterus chitala) for a period of 6 months from January to J une 2010. Thirty live chital fish were used in this study. The mean GSI values for female chital were found to range between $0.20 \pm 0.013$ and $4.63 \pm 0.50$. The highest GSI value was found in June. The smallest diameter of ovum was recorded $0.04 \mathrm{~mm}$ (January) and the largest was $4.00 \mathrm{~mm}$ (June). During the experimental period, the fecundity was ranged from 8,238 to 18,569 (mean $13,052 \pm 4607$ ) in fish samples with body weight range from 1,296 to 2,360 (mean $1,742.50 \pm 474.44 \mathrm{~g}$ ) while the relative fecundity was 5.65 to 14.33 . Histological study revealed that the percentage of late perinucleolus (LPN) stage was highest in April and Cortical alveoli (CA) stage appeared from April and reached to maximum in May. Vitellogenic stage (VG) appeared in the month of May and chronologically increased through J une. Vitellogenic stage (VG) of oocyte as well as highest ova diameter reached to the peak in June. The variations in the gonad weight and GSI of the female fish reached to the peak during June indicating maturity of ovary and definite spawning season.
\end{abstract}

Keywords: Reproductive biology, feather back, chital

Freshwater Station, Bangladesh Fisheries Research Institute, Mymensingh, Bangladesh

*Corresponding author's email: kohinoor41@ gmail.com (A.H.M. Kohinoor)

Reviewed by Dr. Saleh M.A. Mobin, NMIT, Australia.

\section{Introduction}

Feather back, Chital (Notopterus chitala) is a rheophilic important freshwater fish found widely in lenthic waters. This species is widely distributed in deep and clear waters in the rivers, beels, reservoirs, haors, baors and ponds in Bangladesh (Azadi et al., 1994). In recent years, the catch of this species has been declining fast due to environmental degradation (Hossain et al., 2006). This fish is rich in nutritive value and commands high market price despite of the presence of a large number of intramuscular bones. In addition to the above qualities, Chital plays a significant role in regulating the population imbalance that may be caused by wild breeding of common carp, abundance of other minnows and insects in ponds under composite carp culture where strict control on the population size of the stocked fish is essential to obtain optimum production (Chaudhuri et al., 1975). Some progressive farmers are thinking to culture this species in pond with carps using polyculture technique. The fry of chital is not available throughout the year for growing out in the farms for producing marketable size fish, which indicates significance for developing seed production technology of this species. Although literature is available, on the morphometry, food and feeding habits, natural breeding (Singh et al., 1980; Hossain, 1999) of this fish, very scanty systematic attempts have been made to study the reproductive biology and breeding technique in captivity of this fish. This paper reports a detailed account of the reproductive biology of chital.

\section{Materials and Methods}

The study was carried out for the period of six months from January to June 2010 in the Freshwater Station, Bangladesh Fisheries Research Institute, Mymensingh, Bangladesh. Fifty brood fish of chital were stocked in a rearing pond with an area of $400 \mathrm{~m}^{2}$ between August and September. After stocking, 
the brood fishes were fed with live food such as small fish, tilapia fry, small prawn etc. @ 2\% of estimated body weight.

\section{Fish Sample collection}

Five female live fish samples were collected by seine net once in a month from January to J une 2010 from the experimental pond. After collection, live fish were transported to the laboratory and the gonads were removed by opening the peritoneal cavity and were used for the study.

\section{Determination of the reproductive periodicity}

The methods were used to determine the reproductive periodicities of the fish are as follows:

\section{Gonadosomatic Index (GSI)}

Total body weight of selected fishes in each month was considered to calculate the mean Gonadosomatic Index (GSI). Gonadosomatic Index (GSI) was calculated according to the formula:

$$
\text { GSI }=\frac{\text { Weight of gonad }}{\text { Weight of fish }}
$$

\section{Diameter of ova}

After dissecting the overy, small representative part from the anterior, posterior and middle portion of the ovary was removed separately. The ova of the samples were separated using physiological saline solution $(0.65 \% \mathrm{NaCl})$ with a petridish and spread on a glass slide to measure the diameter under a microscope with an ocular micrometer. The units of the ocular micrometer that visible in the microscope were standardized with a stage micrometer for measurement of ova diameter in micrometer

$(\mu \mathrm{m})$. Approximately 300 ova from each sample were measured and ova diameters were determined and were expressed in unit value of the ocular micrometer.

\section{Histology of Gonad}

To study the sequential histological changes, the ovaries tissues were fixed in aqueous Bouin's fluid and then routine histological process was followed for slide preparation. The gonadal tissues were serially sectioned at a thickness of $4 \mu$ and stained with haematoxylin-eosin. From the histological preparation of the gonadal tissues, the cells and nuclear diameters of cells and various oocytes were measured by ocular micrometer.

\section{Results and Discussion}

The different development stages of gonad are presented below:

\section{Gonad observation}

The oval shaped chital ovary was single lobed lying in the body cavity. The size and extent of occupancy of the body cavity were found to vary with size and maturity of the females. Ovary showed the highest weight in June indicating the mature stage. During this time, the colour of the ovary was yellowish. The immature ovary was compact but the matured one was filament like structure (Plate 1).

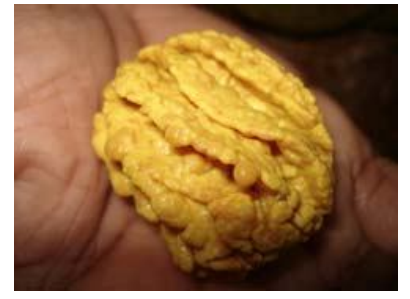

Plate 1. Physical appearance of Chital ovary

\section{Gonadosomatic index (GSI)}

Monthly variations in GSI values of chital are presented in Table 1 and Fig. 1. The mean GSI values of female chital were found to range between $0.20 \pm 0.013$ to $4.63 \pm 0.50$. The greatest GSI value was found in June, which indicates peak period of ovarian growth. It is evident from the results that the GSI values increased slowly from January to March and then sharply increased in June. Thomas et al. (2003) described that gonadosomatic index (GSI) found lowest in early stage and highest in later stage in fin fish and shell fish.

Table 1. Mean and standard deviation $( \pm \mathrm{SD})$ of total body weight, total length, gonad weight and GSI (\%) at successive months of femaleN. Chitala

\begin{tabular}{lccccc}
\hline Month & $\begin{array}{c}\text { No. of fish } \\
\text { examined }\end{array}$ & $\begin{array}{c}\text { Total length } \\
(\mathrm{cm})\end{array}$ & $\begin{array}{c}\text { Bodyweight } \\
(\mathrm{g})\end{array}$ & $\begin{array}{c}\text { Gonad weight } \\
(\mathrm{g})\end{array}$ & GSI (\%) \\
\hline January & 4 & $53.90 \pm 5.90$ & $1178 \pm 131.45$ & $2.34 \pm 0.36$ & $0.20 \pm 0.01$ \\
February & 4 & $60.88 \pm 1.40$ & $1605 \pm 114.65$ & $3.78 \pm 0.40$ & $0.24 \pm 0.02$ \\
March & 4 & $65.85 \pm 0.95$ & $2101 \pm 357.84$ & $11.2 \pm 2.73$ & $0.53 \pm 0.04$ \\
April & 4 & $65.58 \pm 4.98$ & $1855 \pm 463.41$ & $34.52 \pm 14.28$ & $1.80 \pm 0.45$ \\
May & 4 & $66.7 \pm 2.66$ & $2019.75 \pm 206.0$ & $165.55 \pm 23.79$ & $3.21 \pm 0.98$ \\
June & 4 & $67.65 \pm 4.64$ & $2041 \pm 518.19$ & $95.50 \pm 29.86$ & $4.63 \pm 0.50$ \\
\hline
\end{tabular}




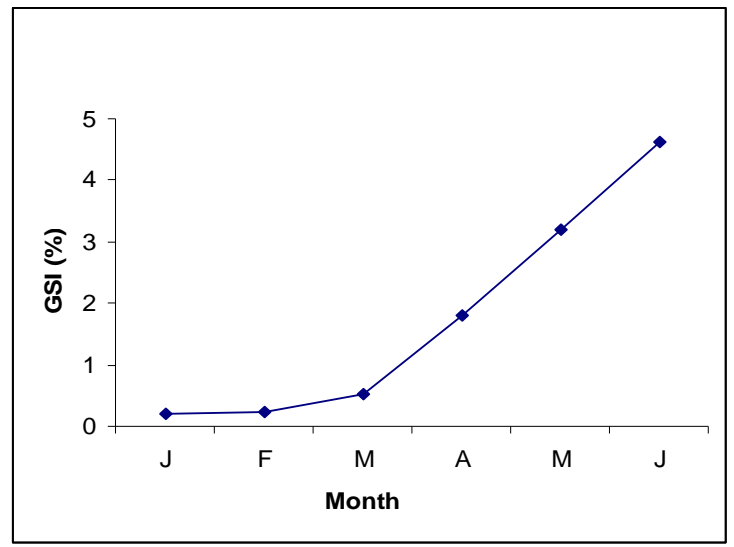

Fig. 1. Monthly trend of changes in Gonadosomatic Index (GSI) of femaleN. chitala

\section{Diameter of ova}

Increasing diameter of ova indicates the development of eggs which is related to approaching the breeding season of fish. The observed ova size at different months indicated that the chital fish become sexually matured between May and J une.

For easy interpretation, the ova were grouped into two categories on the basis of size of diameter i.e. category I $(0.04-0.168 \mathrm{~mm})$ and category-II $(1.00-4.00 \mathrm{~mm})$. The smallest diameter of ovum was recorded $0.04 \mathrm{~mm}$ and the largest was $4.00 \mathrm{~mm}$ during the study period. During January to March, only categoryI oocytes were found and this category was also widely distributed up to June. But in June it was comparatively lower percentage $(66.04 \pm 4.73)$ than other months. During the observation period, mean ova diameter was $0.117 \pm 0.02 \mathrm{~mm}$ and $0.120 \pm 0.03 \mathrm{~mm}$ in February and March, respectively (Table 2).

Table-2 also showed that two categories of ova were observed from April. The ova belonging to category II was found in April with a rapid increase in diameter in May. It was observed that the abundance of category II oocytes were highest in June (34.21 $\pm 6.54 \%)$ and lowest in April (8.86 $\pm 3.38 \%)$. The mean ova diameter of Category I and II, were $0.122 \pm 0.02 \mathrm{~mm}$ and $2.51 \pm 0.54 ; \quad 0.124 \pm 0.021$ and $3.16 \pm 0.89 \mathrm{~mm} ; 0.129 \pm 0.02 \mathrm{~mm}$ and $3.21 \pm 0.47 \mathrm{~mm}$ in the month of April, May and June, respectively (Table 2).

It is mentioned by Rahman (1989) that chital breeds in J une and having an egg size of 3.0 to $4.5 \mathrm{~mm}$ in diameter. While, Radheyshyam and Sarangi (2004) studied the breeding activity and egg incubation of the same species in captivity and observed the diameter of fertilized eggs ranges were 4.8-8.2 mm. Hossain et al., (2006) cultured chital in ponds and found the fertilized eggs having average diameter of 4.5 $\mathrm{mm}$. The results obtained in the present study are consistent with the study mentioned above.

Table 2. Category wise distribution of oocytes during observation period

\begin{tabular}{lccccc}
\hline Groups & \multicolumn{5}{c}{ Months } \\
\cline { 2 - 6 } & February & March & April & May & J une \\
\hline Category-I $(\mathrm{mm})$ & $0.117 \pm 0.02$ & $0.120 \pm 0.03$ & $0.122 \pm 0.02$ & $0.124 \pm 0.021$ & $0.129 \pm 0.02$ \\
Category-II $(\mathrm{mm})$ & - & - & $2.51 \pm 0.54$ & $3.16 \pm 0.89$ & $3.21 \pm 0.47$ \\
\hline
\end{tabular}

\section{Fecundity}

Breeding performance of a fish species depends on different parameters like fecundity, spawning response, fertilization rate, hatching rate, hatching time, size of spawn, yolk sac absorption time period, larval survival rate etc. Therefore, to understand fecundity of this species a study was carried out. In this study fecundity was found to ranged from 8,238 to 18,569 (mean $13,052 \pm 4607$ ), in fish samples with body weight from 1296 to $2360 \mathrm{~g}$ (mean $1742.50 \pm 474.44 \mathrm{~g}$ ) while the relative fecundity were 5.65 to 14.33 (mean $7.99 \pm 4.24 \mathrm{~g}$ ). Details of results are given in Table 3.

Table 3. Mean gonad weight and fecundity of N. chitala

\begin{tabular}{lccc}
\hline Mean. body wt. (g) & Mean gonad wt. (g) & $\begin{array}{c}\text { Mean relative fecundity } \\
\text { (No. of eggs/ g B. Wt.) }\end{array}$ & Mean fecundity \\
\hline $1742.50 \pm 474.44$ & $66.25 \pm 6.80 \mathrm{~g}$ & $7.99 \pm 4.24 \mathrm{~g}$ & $13052 \pm 4607$ \\
$(1296$ to 2360$)$ & $(59.00$ to 73.00$)$ & $(5.65$ to 14.33$)$ & 8238 to 18,569 \\
\hline
\end{tabular}


The results analysis shows a nearly perfect positive linear relationship between fecundity and body weight, where the calculated values of regression coefficient, intercept and coefficient of correlation were 0.1021 , 409.69 and 0.4917, respectively (Fig. 2). Shing et al. (1980) observed natural spawning of chital in pond ecology and estimated the fecundity of the fish to be around 400 eggs $\mathrm{kg}^{-1}$ body weight. In another study, Hossain et al. (2006) reported that fecundity was 5761 eggs of a $4200 \mathrm{~g}$ female weight.

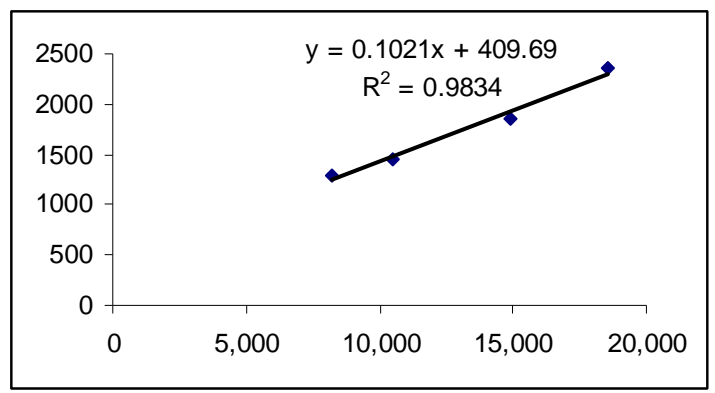

Fig. 2. Relationship between body weight and fecundity of N. chitala

\section{Histology of gonad}

Histological structure of gonad was examined and different stages of oocytes indicated that the oocytes did not develop synchronously. In gonad, different developmental stages of oocyte viz. oogonia (OG), early perinucleolus stage (EPN), late perinucleolus stage (LPN), cortical alveoli stage (CA), vitellogenic stage (VG) were distinguished on the basis of size appearance of nucleolus and cytoplasm. It was found that at the earlier stages of the study period (January/February), all oocytes were found in oogonial stage. Later on, the percentage of oogonia showed a decreasing trend in the successive months.

The highest percentage early perinucleolus stage $(\mathrm{EPN})$ was found in May $(31.00 \pm 2.65 \%)$ with a decreasing trend in the following months. As a result, the percentage of late perinucleolus (LPN) stage was highest in April $(7.67 \pm 1.53 \%)$ and then their appearance was found to decrease gradually. But the oogonia stage, early and late perinucleolus stage showed a decreasing trend from February to June. Cortical alveoli stage (CA) appeared from April and turned greatest in May $(10.67 \pm 2.08 \%)$. Vitellogenic stage (VG) appeared in the month of May and chronologically increased up to June $(33.67 \pm 3.51 \%$. Atretic oocytes (AO) were not found during the study period. Month wise per cent distribution of different development stage of oocytes is shown in Table 4. No literature is available on histology of gonad of this species for comparison.

Table 4. Month wise per cent distribution of different development stage of oocytes in sample of ovarian tissue of Chital

\begin{tabular}{lccccc}
\hline Months & Oogonia & EPN & LPN & CA & VG \\
\hline January & 100 & - & - & - & - \\
February & 100 & - & - & - & - \\
March & $92.67 \pm 1.53$ & $5.33 \pm 1.53$ & $2.00 \pm 0.98$ & - & - \\
April & $76.33 \pm 4.51$ & $14.67 \pm 2.52$ & $7.67 \pm 1.53$ & $1.33 \pm 0.58$ & - \\
May & $25.33 \pm 2.52$ & $31.00 \pm 2.65$ & $6.67 \pm 2.08$ & $10.67 \pm 2.08$ & $26.33 \pm 1.15$ \\
June & $23.67 \pm 3.51$ & $30.33 \pm 2.52$ & $5.00 \pm 1.13$ & $7.33 \pm 0.58$ & $33.67 \pm 3.51$
\end{tabular}

In the present study, five stages of oocyte were February while, it was fully absent in June. identified that were: (a) oogonia, (b) early perinucleolus stage, (c) pre-vitellogenesis, (d) vitellogenesis and (e) maturation stage. These stages of oocyte development in Chital are similar to that of Ompok pabda, Amblypharyngodon mola, Puntius sophor, Puntius gonionotus and Chela cachius (Zakia, 1996; Begum, 1997 and Kohinoor 2000). These developmental stages are seemed to be fairly similar to that of Pleuronectes flesus described by Janseen et al. (1995) who described eight stages of oocyte development in their study. On the other hand, Mollah (1986) observed the oocyte maturation in catfish, Clarias macrocephalus, and identified seven stages: oogonia, chromatin nucleus, early perinucleolus, late perinucleolus, yolk vesicle, early yolk- granule and late yolk-granule stage. In another histological study, the stage of oogonia of L. rohita and C. cirrhossus were found from the month of Jahan, (2008) observed that the EPN and LPN stages appeared from April and the vitellogenic stage (VG) in May.

\section{Conclusion}

The variations in the gonad weight and gonado somatic index (GSI) of the female chital fish reached to the peak during June indicating maturity of ovary and definite spawning season. While Vitellogenic stage (VG) of oocyte as well as highest ova diameter was observed in June also. The present study on reproductive biology of chital may contribute to the seed production technology of this fish species in captivity, which may prelude to their introduction as a potential candidate for aquaculture and paves the way to conserve this endangered native fish species. 


\section{References}

Azadi, M.A., Mahamood, N. and Shafi, M. 1994. Studies on the age and growth of Chital, Notopterus chitala (Ham.) from the Kaptai Reservoir, Bangladesh. Chittagong Univ. Studies., 18 (2): 197-205.

Begum, K. 1997. A study on the histological analysis of gonadal development, fecundity, embryonic and larval development of Ompok pabda (Hamilton-Buchanan 1822). M. Sc. Dissertation, Department of Zoology, Dhaka University. 108 p.

Chaudhuri, H., Chakrabarty, R.D., Sen, P.R., Rao, N.G.S. and J ena, S. 1975. A new high in fish production in India with record yield by composite fish culture in freshwater ponds. Aquaculture, 6: 343-355.

Hossain, Q.Z. 1999. Some observations on breeding and fry rearing of chital (Notopterus chitala, Hamilton) in Bangladesh. Fishing Chimes., 19 (7): 13-16.

Hossain, Q.Z., Hossain, M.A. and Parween, S. 2006. Breeding biology, captive breeding and fry nursing of humped featherback (Notopterus chitala, Hamilton-Buchanan, 1822). Ecoprint, 13: 41-47

Jahan. D.A. 2008. Substitution of fishmeal protein by soybean meal protein in the diet of two Indian major carps. Ph.D. Dissertation, Department of Fisheries Biology \& Genetics, Bangladesh Agricultural University, Mymensingh. 268p.

J anseen, P.A.H., Lambert, J.G.D. and Goos, H.J .T. 1995. The annual ovarian cycle and the influence of pollution on vitellogenesis in the flounder, Pleuronectes flesus. J. Fish. Biol., 47: 509-523.

Kohinoor, A.H.M. 2000. Development of culture technologies of three small indigenous fish mola (Amblypharyngodon mola), punti (Puntius sophore) and chela (Chela cachius) with notes on some aspects of their biology. Ph.D. Dissertation, Department of Fisheries Management, Bangladesh Agricultural University, Mymensingh. 366p.

Mollah, M.F.A. 1986. Cycle changes in the ovary of freshwater catfish, Clarias macrocephalus (Gunther). Indian J . Fish., 33 (1): 54-65.

Radheyshyam and Sarngi, N. 2004. Breeding for sac-fry production of feather back fish Notopterus chitala Hamilton) in control condition. Abstract, Souvenir Natl. Semi. Zoology and Human Welfare, 22-24 Nov. 2004 at Dr. S. P. Mukherjee Govt. Deg. College of Allahabad University, Phapharman, Allahabad, 16p.

Rahman, A.K.A. 1989. Freshwater Fishes of Bangladesh. Zoological Society of Bangladesh. 364 p.

Shing, S.B., Dey, R.K., Reddy, P.V.G.K. and Mishra, B.K. 1980. Some observation on breeding, growth, and fecundity of Notopterus chitala. J. Inland Fish. Soc. India, 12 (2): 13-17.

Thomas-J ones, E., Thorpe, K., Harrison, N., Thomas, G., Morris, C. and Hutchinson, T.H. 2003. Dynamics of estrogen biomarker responses in rainbow trout exposed to $17 \beta$-estradiol and $17 \alpha-$ ethinylestradiol. Environ. Toxicol. Chem., 22: 3001- 3008.

Zakia, A. 1996. Comparative studies on the gonadal histology and morphology of different interaspecific hybrids of Puntius gonionotus (Bleeker, 1849). M. Sc. Dissertation, Department of Zoology, Dhaka University, Dhaka. 138p. 


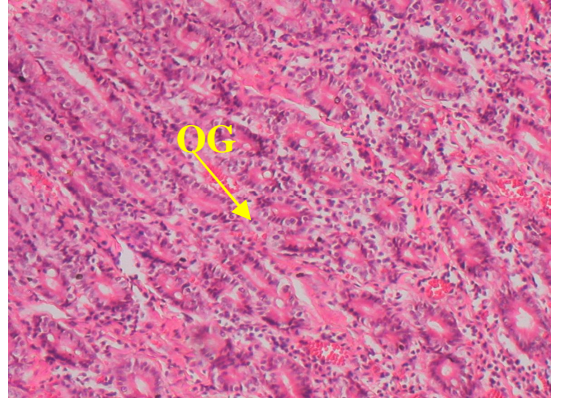

January

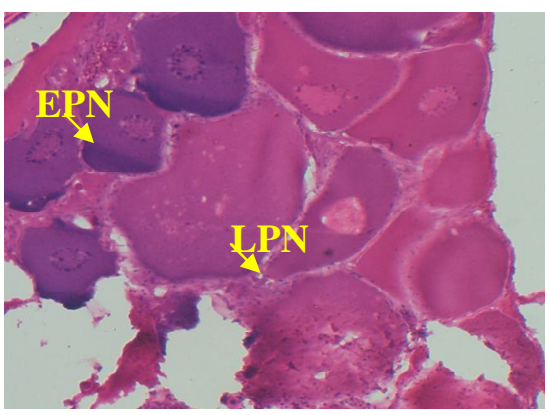

March

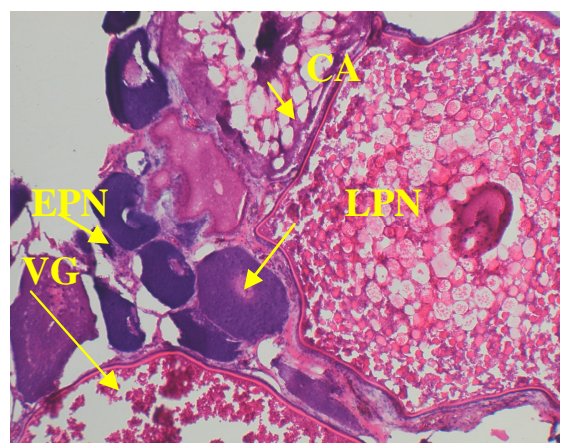

May

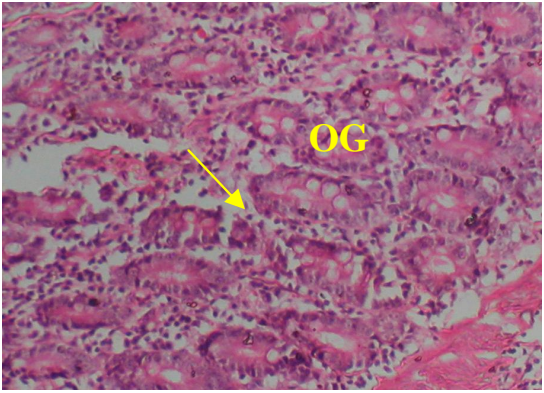

February

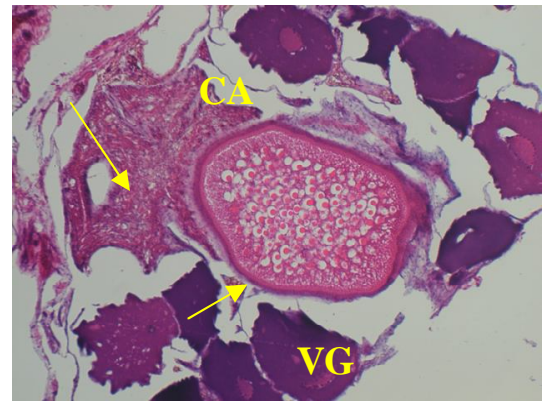

April

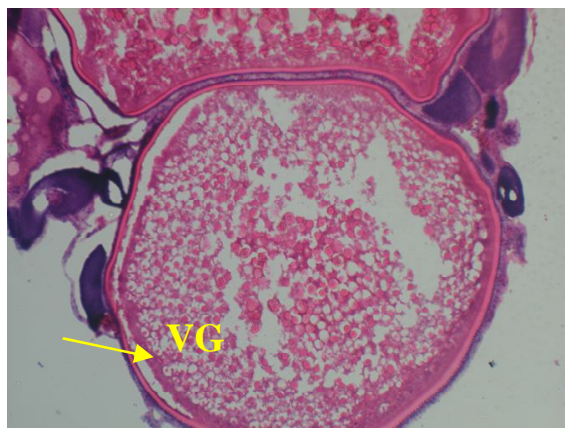

June

Plate 2. Developmental stage of Oocytes in different months 